\title{
Impact of the Brazilian Accounting Pronouncements Committee's New Guideline (OCPC 07) on the downsizing of companies' Notes ${ }^{*}$
}

\author{
Edilene Santana Santos ${ }^{1}$ \\ (D) https://orcid.org/0000-0002-0230-9357 \\ Email: edilene.santos@fgv.br \\ Laura Calixto ${ }^{2}$ \\ (D) https://orcid.org/0000-0002-9207-2794 \\ Email: laura.calixto@unifesp.br \\ Maira Ferreira Bispo² \\ (D) https://orcid.org/0000-0002-4090-3015 \\ Email: maira.fb@outlook.com.br
}

\begin{abstract}
'Fundação Getúlio Vargas, Escola de Administração de Empresas de São Paulo, Departamento de Contabilidade, Finanças e Controle, São Paulo, SP, Brazil

¿Universidade Federal de São Paulo, Escola Paulista de Política, Economia e Negócios, Departamento de Ciências Contábeis, Osasco, SP, Brazil
\end{abstract}

Received on 09.28.2017 - Desk acceptance on 10.27.2017 - $4^{\text {th }}$ version approved on 06.21.2018 - Ahead of print on 11.01.2018

Associate Editor: Eliseu Martins

\begin{abstract}
This article aims to assess the impact of the New Guideline of the Brazilian Accounting Pronouncements Committee (Comitê de Pronunciamentos Contábeis - OCPC 07) on improving formal features (size, readability, and specificity) of Brazilian companies' Notes. OCPC 07 is one of the world's first guidelines issued in response to the current demand for the downsizing of companies' Notes, which according to standard setters and market agents have become too extensive, thus characterizing a disclosure overload. This is a unique study on the subject. The results suggest the effectiveness, although limited, of the new standard in promoting a departure from the habits of secrecy and formalism rooted in centuries of legalaccounting civil law tradition, and indicate that there is still room for complementary improvement initiatives in the form of incentives for firms and increased enforcement. Three complementary methodological approaches are used: (1) an analysis of both the evolution of note size after OCPC 07 and the factors explaining that size and its variation; (2) an examination of indicators of readability, conciseness, and specificity of the note on accounting policies; and (3) a size comparison of the Notes of Brazilian and British companies, a benchmark of the common law tradition. An average reduction of $10 \%$ in Note size was found two years after the introduction of Guideline (Orientação) 07 by the (OCPC 07). This downsizing was not generalized, but instead identified only among firms in the Novo Mercado and among those audited by two of the Big Four. Even in firms that reduced their notes by at least $20 \%$, no significant improvements in readability levels could be perceived, nor in habits of copy-pasting the auditors' templates, which could signal a focus on firms' real practices in the note on accounting policies. Brazilian Notes remain far from the benchmark and are still $40 \%$ longer than British ones, despite an equivalent number of pages being expected.
\end{abstract}

Keywords: OCPC 07, notes, financial statements, downsizing, readability.

Correspondence address

Edilene Santana Santos

Fundação Getúlio Vargas, Escola de Administração de Empresas de São Paulo, Departamento de Contabilidade, Finanças e Controle Avenida Nove de Julho, 2029, 2 Andar - CEP: 01313-902

Bela Vista - São Paulo - SP - Brazil

*Paper presented at the XLI ANPAD Conference, São Paulo, SP, Brazil, October 2017. 


\section{INTRODUCTION}

Since the adoption of the International Financial Reporting Standards (IFRS) in Brazil, in 2010, their assimilation by companies has revealed a dichotomy to researchers. On one hand, the benefits of IFRS are well-known, being rooted in the Anglo-American common law tradition and prioritizing essence over form and promoting information transparency for the investor, thus increasing the comparability and visibility of companies in the global capital market (Ball 2006; Gray, 1988; Leuz \& Wysocki, 2016). On the other hand, the disclosure required by IFRS appears to not yet satisfactorily integrate company practices, especially in countries with the civil law tradition, such as Brazil, where the secrecy and formalism that have shaped their institutions over the centuries still persist (Daske, Hail, Leuz \& Verdi, 2013; Nobes, 2013; Santos, Ponte \& Mapurunga, 2014b). This tension between the acceptance of the international norms per se (convergence de jure) and their effective materialization in companies' real practices (convergence de facto) has created the phenomenon of disclosure overload (IFRS, 2013): Notes inflated by long-winded texts, including literal copies of the norm, but lacking relevant and required content.

In fact, after IFRS, an increase in Note size has been observed: the European Financial Reporting Advisory Group (EFRAG, 2012) mentions that the reports of one big pharmaceutical company had become six times longer since 1990; the Brazilian Social and Economic Development Bank (BNDES) increased the size of its Notes by $100 \%$ with IFRS (Martins, 2011).

Nonetheless, Santos et al. (2014b) found only a 34\% degree of compliance with the disclosure required by IFRS in its first year of adoption in Brazil. Also, a study by the Securities and Exchange Commission (SEC) on the adoption of IFRS in 183 companies in the world finds that

many companies did not appear to provide sufficient detail or clarity in their accounting policy disclosures to support an investor's understanding of the financial statements, including in areas they determined as having the most significant impact on the amounts recognized in the financial statements. (SEC, 2011, p.2)

This phenomenon of lengthy Notes that are hard to read and lack relevant information has been of concern to regulatory bodies and given rise to demands around the world for them to be lean, relevant, and readable (EFRAG, 2012; FASB, 2012; IFRS, 2013; SEC, 2011).

In fact, the literature confirms the importance of the readability of financial reports for the capital market: greater readability is positively associated with company returns (Subramanian, Insley \& Blackwel, 1993), it reduces analyst forecasting errors (Lehavy, Li \& Merkley, 2011), decreases the cost of capital (Dempsey, Harrison, Luchtenberg \& Seiler, 2010), increases liquidity in the market (Choudhary, Schiotzer \& Sturges, 2013; Miller, 2010), and reduces costs and agency conflicts (Hui \& Matsunaga, 2015).

In light of this global discussion and studies indicating disclosure shortcomings in Brazil, in a world-first initiative, in September of 2014 the Accounting Pronouncements Committee published Guideline 07 (OCPC 07), taking effect from 2015 and emphasizing that "only information relevant and specific to the entity should be disclosed" (OCPC 07, item 30).

Along the same lines, in December of 2014, the International Accounting Standards Board (IASB) published the Disclosure Initiative (Amendments to IAS 1), taking effect in 2016 and stressing that "(1) information should not be obscured [...] by providing immaterial information, (2) materiality considerations apply to all parts of the financial statements, and (3) even when a standard requires a specific disclosure, materiality considerations do apply".

In this context, this study aims to answer the following main question: after the first two years of OCPC 07 being in effect $(2014,2015)$, was there an improvement in formal aspects (size, readability, and specificity) of Brazilian companies' Notes?

This general question divides into six specific questions: (1) Did the size of Brazilian companies' Notes decrease? (2) What factors explain the size of Brazilian companies' Notes? (3) If there was a reduction in Note size, what factors would explain this reduction? (4) Was there an improvement in readability? (5) Was the undesired practice of simply copy-pasting generic texts from the norms overcome? (6) In order to exemplify, how does the new size of Brazilian companies' Notes compare with those of British companies, considered a benchmark for transparency?

No other study was found that has investigated these questions. 


\section{THEORETICAL FRAMEWORK}

\subsection{Disclosure Theory and Disclosure Overload}

The literature on disclosure focuses on the tension between the advantages of transparency and the advantages of secrecy (Verrecchia, 2001) in business. Investors demand the disclosure of both good and bad company news, as a factor of safety, credibility, and risk-avoidance (Dye, 2001; Healy \& Palepu, 2001; Verrecchia, 2001). The greater the transparency, the greater the company's attractiveness to the investor, reflected in a reduction in the cost of capital (Lambert, Leuz \& Verrecchia, 2011, Verrecchia, 2001), in greater liquidity of shares (Diamond \& Verrecchia, 1991) and in higher accuracy of analysts' forecasts (Eaton, Nofsinger \& Weaver, 2007; Santos, Silva, Sheng \& Lora, 2016). After investment, transparency is a condition for overcoming agency conflicts between shareholders and managements (Healy \& Palepu, 2001).

However, various authors have observed that companies resist disclosure to protect owner confidentiality in face of competitors, hostile investors, legal disputes, and employees demands (Dye, 2001; Verrecchia, 2001). Less disclosure, however, leads to "adverse selection" by confusing good and bad firms (Akerlof, 1970), thus making mandatory disclosure a public good, enhancing market efficiency (Healy \& Palepu, 2001). The recent globally discussed phenomenon of disclosure overload - an excessive volume of non-relevant, generic (non firm specific), and difficult to read information - can therefore be understood as a new form of non-disclosure and resistance to disclosure.

\subsection{Disclosure and Legal-Accounting Tradition}

The literature distinguishes between two basic accounting system traditions: in Anglo-American influenced countries, the common law legal and accounting tradition prioritizes free initiative and the investor market, adopts distinct accounting practices for company management and tax purposes, and values those that best reflect companies' economic reality, encouraging transparency and disclosure; countries with a continental European civil law influence emphasize legalism and accounting formalism, with a focus on tax authorities and creditors and a tendency for secrecy, which does not encourage transparency and disclosure (Archambault \& Archambault, 2003; Gray, 1988; Hope, 2003; Zarzeski, 1996).
With the global adoption of IFRS emerging from the common law tradition, its assimilation has been studied, especially in countries with a civil law tradition, such as Brazil. In fact, studies have confirmed that expressive differences remain in the levels of disclosure between companies with different accounting traditions, even after IFRS adoption (Glaum, Schmidt, Street \& Vogel, 2013; Nobes, 2013). For example, Santos, Schiozer, and Ponte (2016) verified that companies from the England disclose, on average, 34\% more required information about related parties than Brazilian companies. Comparing the Notes of telecommunications firms, Lourenço (2013) observes that in 44 pages the British company Vodafone manages to provide more relevant information for the user than Portugal Telecom in 125 pages. Thus, for the purposes of this study, it could be conjectured that Brazilian firms' Notes tend to be longer and more inflated than those of British companies.

\subsection{Disclosure and Readability}

As mentioned, one form of non-disclosure is characterized by obscure and difficult to read Notes that hide relevant information (EFRAG, 2012).

In 1998, the SEC already identified the need for greater clarity of language in reports, especially for the small investor, in the program Plain English (SEC, 1998) - How to create clear SEC disclosure documents, prefaced by Warren Buffet, which observes that a lack of clarity can be intentional in order to conceal information.

For more than forty years, I've studied the documents that public companies file. Too often, I've been unable to decipher just what is being said or, worse yet, had to conclude that nothing was being said [...] There are several possible explanations as to why I and others sometimes stumble over an accounting note or indenture description. Maybe we simply don't have the technical knowledge to grasp what the writer wishes to convey. Or perhaps the writer doesn't understand what he or she is talking about. In some cases, moreover, I suspect that a less-than scrupulous issuer doesn't want us to understand a subject it feels legally obligated to touch upon (SEC, 1998, p. 1)

Various studies have examined the correlation between clarity of disclosure, compliance with standards, and market perception. Choudhary et al. (2013) examine, in compliance with the SEC, the relationship between completeness, timeliness, and readability of disclosure. Dempsey et al. (2010) verify that the opacity (low readability) of reports, in avoiding bad news, conceals 
the performance of companies and increases their cost of capital. Subramanian et al. (1993) study the relationship between performance and the readability of disclosure, concluding that profitable companies present clearer texts than non-profitable ones. Li (2008) concludes that the reports of firms with lower profits are more difficult to read (they are longer and less readable). Lehavy et al. (2011) investigate the effect of the readability of the disclosure in $10-\mathrm{K}$ forms, verifying that less clarity is associated with greater dispersion, imprecision, and uncertainty in analyst forecasts. Miller (2010) studies the effect of the complexity of reports on investment transactions and associates complex disclosures with low small investor activity in the capital market. Lo, Ramos, and Rogo (2017) associate low readability of annual reports with earnings management practices.

Various authors, such as Li (2008), Miller (2010), Lehavy et al. (2011), and Lo et al. (2017), use computerized formulas, especially the Gunning-Fog Index, or simply the Fog Index (Gunning, 1969), which calculates the number of words per sentence and of complex words in a text to determine its readability. Others, such as Loughran and McDonald (2014), criticize the use of computerized readability indices and prefer an own system for measuring readability. The SEC (1998) also takes a critical stance, recommending caution in the use of readability formulas in financial information.

Readability formulas determine how difficult a piece of writing is to read. However, you should be aware of a major flaw in every readability formula. No formula takes into account the content of the document being evaluated. In other words, no formula can tell you if you have conveyed the information clearly (SEC, 1998, p. 57)

Given these criticisms, in this study the readability of Brazilian companies' Notes is analyzed using various complementary methodologies, as will be detailed (items 3.2.1 and 4.2).

\subsection{Explanatory Factors for Note size and Variations in Note size}

As mentioned, one of the aims of this study is to address the explanatory factors for both the size of Notes and for the variations in their size after OCPC 07.
It is to be assumed that, in normal conditions, Note size is a proxy for the level of disclosure (that is, more transparent firms would tend to have longer Notes). Thus, it is assumed that the same factors traditionally associated with greater disclosure would also act in influencing Note size. However, the generalized criticisms of excessive Note size, which creates obscurity, lead it to be expected that the same factors that positively affect Note size also influence their downsizing. Thus, if longer Notes do not necessarily indicate greater transparency, in the reduction of Notes, in order to gain transparency, the same factors that encourage disclosure would come into play.

The literature indicates a positive association between disclosure and various main factors: company size (Archambault \& Archambault, 2003; Santos et al., 2014b; Street \& Gray, 2002; Zarzeski, 1996), the adoption of differentiated governance policies (Santos et al., 2014b, 2014a), being audited by global auditing firms - Big Four (Santos et al., 2014b; Street \& Gray, 2002), and having an international listing, especially on the New York Stock Exchange (NYSE) in the form of American depositary receipts (ADRs) (Archambault \& Archambault, 2003; Leuz \& Wysocky, 2016; Street \& Bryant, 2000).

In this study, these factors are taken as control variables to explain the Note size and its variation after OCPC 07.

As well as these, this study examines two additional explanatory factors:

1. Belonging to a highly regulated sector. It is supposed that companies belonging to highly regulated sectors (oil and gas, electrical energy, and telecommunications) face disclosure requirements by multiple regulators, which would lead to longer Notes and tend to restrict any downsizing of Notes resulting from OCPC 07 [see, for example, Santos et al. (2014a)].

2. The size of the company's Notes in the year before OCPC 07 was issued. It is supposed that the longer the Notes before OCPC 07, the greater the likelihood of them being downsized, since the opportunity for and benefits of a reduction are greater, including reduced publication costs. Thus, companies with longer Notes in the year before OCPC 07 are expected to present a greater reduction in their Notes when it comes into effect.

\section{METHODOLOGY}

This study uses three complementary methodological approaches, aiming to (i) analyze the evolution of Note size with OCPC 07 and the factors explaining that size and its variation; (ii) examine indicators of readability, concision, and specificity of the note on accounting policies; and (iii) compare the size of Brazilian and British companies' Notes. 


\subsection{Methodology for Analyzing the Evolution of Note size and Explanatory Factors}

\subsubsection{Sample and data}

The analysis of Note size before and after OCPC 07 is carried out by taking the Notes of all the non-financial firms listed in the B3 in 2010 (year of IFRS adoption), 2013 (year immediately before OCPC 07 adoption), and 2014 and 2015 (first and second years OCPC 07 was in effect). The year of 2010 is included to distinguish possible variations in Note size associated with the learning curve since IFRS adoption (2013 vs. 2010) from the variations attributable to the adoption of OCPC 07 (2014 vs. 2015 vs. 2013). Two proxies are used for Note size: the number of words and the number of pages.

The Note files on PDF were collected from the Brazilian Securities and Exchange Commission (CVM) website, in the Standardized Financial Statements section. To measure the number of words and the number of pages, the WordCount software was used.

After eliminating those companies whose Notes for the period were not available and those whose files were in image format, making counting impossible, the sample totaled 314 companies for the 2010, 2013, and 2014 financial years and 304 companies for the 2015 financial year.

$$
S I Z E_{E N}=\beta_{0}+\beta_{1} S I Z E+\beta_{2} S_{-} E E+\beta_{3} G O V+\beta_{4} B I G 4+\beta_{5} A D R+\beta_{6} Y E A R+\varepsilon
$$

issuer listed on the NYSE, and 0 otherwise), and YEAR in which $S I Z E_{E N}$ is the size of the note, measured by the number of words, SIZE is the size of the company, measured by the Neperian logarithm of its total assets, $S \_E E$ is the electrical energy sector, after the bivariate tests indicated that the firms from the electrical energy sector behaved differently from those from the other regulated sectors (this sector was introduced in the regression model as a binary variable: 1 if the company is from the electrical energy sector, and 0 otherwise), $G O V$ is the corporate governance, a listing in one of the special corporate governance segments of the B3 (after the bivariate tests indicated different behavior per level of listing, each special level of listing - N1, N2, and N3 - was tested separately as a binary variable: 1 if the company belongs to each one of the special corporate governance segments, and 0 otherwise), BIG4 is the auditing firm, indicating whether the company is audited by a Big Four firm (after the bivariate tests indicated different behavior for some auditing firms, each one is analyzed separately: 1 if the company is audited by a specific Big Four firm, and 0 otherwise), $A D R$ is the company issuing ADRs on the NYSE, indicating whether the company has ADRs listed on the NYSE or not ( 1 if the company is an ADR of their assets were obtained from the Economatica ${ }^{\circledR}$ database; the roll of the companies listed in special governance sections was collected from the B3 website; the name of the auditing company was taken from the Reference Form, on the CVM website; and the list of firms issuing ADRs on the NYSE was extracted from the Bank of New York website (www.adrbny.com).

\subsubsection{Modeling and analysis of the factors explaining Note size and its variance}

The analysis of the impact of OCPC 07 on Note size is carried out using descriptive statistics and the mean difference $t$ test (the Kolmogorov-Smirnov test indicated that the data follow a normal distribution). To analyze the factors that determine Note size, as well as its variation variables mentioned are examined as explanatory factors of disclosure levels.

The statistical analysis indicated similar results both for the number of words and for the number of pages; therefore, for concision, in the analysis of the explanatory factors, only the results using the number of words as a proxy for size are presented.

After a bivariate analysis of each explanatory variable, the following regression model was reached, as shown in equation 1 :
The list of companies, their sectors, and the value with the introduction of OCPC 07 , the commonly tested of each year OCPC 07 is in effect ( 1 for each year OCPC 07 is in effect - 2014 or 2015 - and 0 otherwise).

In this event study (the introduction of OCPC 07), it is important to identify possible differences in the behavior of the explanatory variables in the year before the event and in each year it applies, which implies the convenience of a cross-sectional regression. Standard tests for regression analysis using the Stata software confirmed the adequacy of the model.

The explanatory factors for the "variation" in Note size, both in the year of OCPC 07 adoption and after it being in effect for two years, were studied using bivariate analysis. The same explanatory variables for Note size were taken and the variable for Note size in the year immediately before OCPC 07 (2013) was added.

\subsection{Methodology for Analyzing the Note on Accounting Policies}

A more in-depth analysis focuses on the effect of OCPC 07 specifically on the note on accounting policies, which 
has been the biggest target of criticism, given the practice of copy-pasting. For this (after verifying an average reduction of $10 \%$ in Note size), those companies were taken whose Notes reduced in size by at least $20 \%$ in the first year OCPC 07 was in effect, measured both in terms of words and in number of pages, encompassing 62 firms. The size of the note on accounting policies was calculated, along with the proportion between the size of the note and the total for the company's Notes, and the indices for readability and similarity of the note with the auditor's template.

\subsubsection{Measuring the readability index}

Besides the readability indices discussed in the previous section, the readability of the text is analyzed here using three complementary metrics.
The Fog Index (equation 2) assumes that the text will be harder to read the greater the number of words per sentence and the greater the use of complex words, defined as words that contain three or more syllables (Gunning, 1969). However, although in the English language words with three or more syllables can be considered complex, it is hard to say the same for the Portuguese language [see, for example, Martins, Ghiraldelo, Nunes, and Oliveira (1996)]. Therefore, to enhance the robustness of the results, the average length of the sentences (number of words divided by the number of sentences) and the average length of the paragraphs (number of words divided by the number of paragraphs) are calculated. The data for calculating these indices were obtained using the Character Count tool (https://charactercounttool.com).

\section{$F O G=0.4$ (average words per sentence + percentage of complex words)}

\subsubsection{Measuring the index of similarity with the auditor's model note}

The similarity index measures whether OCPC 07 leads to an improvement in the frequent and widely criticized practice of copy-pasting. This practice makes the note on accounting policies a mere literal copy of the text on the norm, instead to describing the company's real accounting policies. For this, a fictitious EN template is used, made available by the main auditing firms to guide clients in preparing their own Notes. Despite this availability being commendable, many companies limit themselves to literally replicating the template.

The index for the similarity of the note on accounting policies with the auditor's template is calculated using the Plagius software, which measures the percentage of plagiarism (similarity) of the text in relation to texts indicated as a base. It is assumed that the greater the percentage of similarity of the note on accounting policies in relation to the auditor's model note, the more generic and less informative the company's note tends to be.

For the analysis, the subsample of 62 companies was limited to only those audited by one of the Big Four and that did not change auditor between 2013 and 2014, totaling a final sample of 44 samples. The analysis is carried out by tests of difference between the means of the similarity indices for 2013 (before OCPC 07) and 2014 (first report under OCPC 07).

\subsection{Methodology for Comparing Brazilian versus British Notes' size}

To complement the analysis, for illustrative purposes only, this study compares the size of Brazilian and British Notes in 2015 (after two years of OCPC 07 being in effect).
The aim is to verify whether the adjustments in the Notes carried out by the Brazilian companies after OCPC 07 were enough to make their size similar to those of British companies, considered a benchmark for characteristics incentivizing transparency: the common law legalaccounting tradition, a high degree of institutional enforcement, and the economic incentives of a highly developed capital market.

For greater comparability, the following procedures were adopted:

- All the non-financial companies listed on the London Stock Exchange and in the B3 in 2015 were identified, using the Bloomberg database.

- The companies of the two countries with less than US\$ 500 million in total assets were eliminated (companies' total assets are captured from Bloomberg in US dollars).

- As the British capital market is bigger and more diversified than the Brazilian one, companies belonging to the sectors that are not present in the Brazilian stock exchange were eliminated from the sample of British ones (Bloomberg GIGS sector classification).

- The Brazilian companies' Notes and the Annual Report of the British companies were collected from the websites, respectively, of the CVM and the company. For the British companies, the other reports were excluded from the Annual Report so that only the Notes remained. After converting the Notes to Word, in order to enable the analysis, those files that presented a conversion error were excluded. The final sample totaled 106 Brazilian companies and 176 British companies, from eight sectors. 
The analysis is carried out using descriptive statistics of the number of pages and a difference of means test.

It is worth noting that the belief that texts in Portuguese would be longer than their counterparts in English is not backed in current computer supported studies. According to Frankenberg-Garcia (2002, 2014), an analysis by the system Compara of a twodirectional English-Portuguese corpus (a computerized set of numerous texts and their English-Portuguese translations and vice-versa) shows no scientific evidence for this belief:
The conventional wisdom is that Portuguese is generally more wordy than English, and that Portuguese translations tend to be longer than their corresponding English source texts, while English translations tend to be shorter than Portuguese source texts. This language-dependent bias is at odds with a more general theory of universals of translation (Frankenberg-Garcia, 2002, p. 5);

and further:

when translating from English to Portuguese, provided that there are no major changes in content, it is unlikely that word counts will increase in the process [...] Thus [...] one cannot say that translation will expand the text. (Frankenberg-Garcia, 2014, p. 162-163)

\section{RESULTS}

The results are structured in three sections: (1) evolution of Note size after OCPC 07 and explanatory factors for Note size and its reduction; (2) analysis of size and indices of readability and similarity with the auditor's template in the note on accounting policies; and (3) comparison of the Notes from 2015: Brazilian versus British companies.

\subsection{Evolution of Note size in Brazil after OCPC 07 and Explanatory Factors}

\subsubsection{Note size before and after OCPC 07}

Panel A of Table 1 presents the descriptive statistics for the size of the companies' Notes measured both by the number of words and by the number of pages in the year of IFRS adoption (2010), in the year immediately before OCPC 07 came into effect (2013), in its first year in effect (2014), and two years after it had been in effect (2015).

The test for possible variations in Note size attributable to the learning curve since IFRS adoption (2010 vs. 2013) reveals: (i) from the number of words, there was no statistically significant variation in size: $50 \%$ of the companies presented longer Notes, while the other half had shorter Notes; (ii) the number of pages shows a slight fall of around 6\% (from 61 pages in 2010 to 57 in 2013), significant at 5\%, with $65 \%$ of the Notes in 2013 having at least one page less than in 2010. However, the apparent reduction in the number of pages from 2010 to 2013 must be taken with caution for two main reasons: (i) the simple exclusion of the Initial Adoption of IFRS note, present in 2010 and not applicable in the other years, would already lead to a natural fall in Note size (in AES Eletropaulo, for example, this note accounted for 4,521 of the 41,061 words - $11 \%$ - and 14 of the 119 pages); (ii) the variation in the number of pages may derive from the differences in the configuration of the text or the tables and fonts used, since the number of pages decreased by an average of $6 \%$, without altering the number of pages.

These results suggest that the learning curve, three years after IFRS adoption in Brazil, does not appear to have acted in reducing the companies' Notes, which highlights the opportunity OCPC 07 created as a stimulus for downsizing Notes in Brazil.

Comparing Note size in 2013 with that of the period OCPC 07 was in effect, a slight reduction is perceived, in the order of $7 \%$ in the first year and $10 \%$ after it was in effect for two years (both significant at 1\%), independent of whether measuring by the number of words or by the number of pages. After two years of it being in effect, more than $60 \%$ of the companies reduced the size of their Notes, both in number of words and pages, by at least $10 \%$ in more than $40 \%$ of the companies. The degree of reduction increased from the first to the second year of OCPC 07 being in effect, indicating that the downsizing of the Notes was not an isolated event, restricted to the year the guideline was adopted, but that it had continuity and became generalized in the second year of it being in effect: the reduction of at least $10 \%$ in the number of words occurred in $29 \%$ of the companies from 2013 to 2014 and in $41 \%$ of the companies from 2013 to 2015; the tendency is similar with regards to the number of pages.

Thus, assuming the perception that the Notes were inflated, the results suggest that the introduction of OCPC 07 had some effectiveness, even though limited, in terms of their downsizing, since the reduction of 6-7\% in the first year and $9-10 \%$ after two years cannot be attributed to the simple effect of the learning curve since IFRS adoption. 
Table 1

Evolution of Notes size

\begin{tabular}{|c|c|c|c|c|c|c|c|c|}
\hline \multicolumn{9}{|c|}{ Panel A: Descriptive statistics } \\
\hline & \multicolumn{4}{|c|}{ Number of words } & \multicolumn{4}{|c|}{ Number of pages } \\
\hline & 2010 & 2013 & 2014 & 2015 & 2010 & 2013 & 2014 & 2015 \\
\hline Mean & 16,729 & 17,218 & 16,167 & 15,705 & 61 & 57 & 53 & 52 \\
\hline Median & 16,512 & 16,766 & 15,608 & 15,194 & 60 & 54 & 50 & 50 \\
\hline Minimum & 969 & 505 & 491 & 89 & 4 & 2 & 2 & 3 \\
\hline Maximum & 63,425 & 67,131 & 66,233 & 64,378 & 235 & 191 & 223 & 206 \\
\hline \multicolumn{9}{|c|}{ Panel B: Variation in size } \\
\hline & \multicolumn{2}{|c|}{$2013 / 2010$} & $2014 / 2013$ & $2015 / 2013$ & \multicolumn{2}{|c|}{ 2013/2010 } & $2014 / 2013$ & 2015/2013 \\
\hline Variation in mean & \multicolumn{2}{|c|}{1.03} & 0.94 & 0.91 & \multicolumn{2}{|c|}{0.94} & 0.93 & 0.90 \\
\hline Shorter Notes & \multicolumn{2}{|c|}{$49 \%$} & $65 \%$ & $61 \%$ & \multicolumn{2}{|c|}{$65 \%$} & $57 \%$ & $63 \%$ \\
\hline Same-sized Notes & \multicolumn{2}{|c|}{-} & - & - & \multicolumn{2}{|c|}{-} & $10 \%$ & $8 \%$ \\
\hline Longer Notes & \multicolumn{2}{|c|}{$51 \%$} & $35 \%$ & $39 \%$ & \multicolumn{2}{|c|}{$35 \%$} & $33 \%$ & $30 \%$ \\
\hline Reduction $>=20 \%$ & \multicolumn{2}{|c|}{$14 \%$} & $13 \%$ & $22 \%$ & \multicolumn{2}{|c|}{$13 \%$} & $16 \%$ & $26 \%$ \\
\hline Reduction $>=10 \%$ & \multicolumn{2}{|c|}{$31 \%$} & $29 \%$ & $41 \%$ & \multicolumn{2}{|c|}{$29 \%$} & $37 \%$ & $47 \%$ \\
\hline Increase $>=10 \%$ & \multicolumn{2}{|c|}{$38 \%$} & $17 \%$ & $21 \%$ & \multicolumn{2}{|c|}{$17 \%$} & $17 \%$ & $19 \%$ \\
\hline Increase $>=20 \%$ & \multicolumn{2}{|c|}{$27 \%$} & $8 \%$ & $11 \%$ & \multicolumn{2}{|c|}{$8 \%$} & $7 \%$ & $13 \%$ \\
\hline Panel C: Test for me & $t$ test) & & $* * *$ & $* * *$ & \multicolumn{2}{|c|}{$* *$} & $* * *$ & $* * *$ \\
\hline
\end{tabular}

$*, * *, * * *=$ levels of significance of 10,5 , and $1 \%$, respectively.

Source: Elaborated by the authors.

\subsubsection{Explanatory factors for Note size before and after OCPC 07}

Firstly, $t$ tests for means were carried out for each binary variable with explanatory potential for Note size (not presented here for concision). The results show that, taken in isolation (bivariate analysis), practically all the variables analyzed have a positive association with Note size.

Table 2 presents the results of the multiple regression model described in equation 1 and used to identify the explanatory factors for Note size (number of words) each year, as well as using the triplicate base of the three years, with the first year and second year OCPC 07 was in effect serving as dummy variables. The regression model is significant at $1 \%$ and strong, explaining more than $60 \%$ of the differences in size between the Notes.

The results show a negative relationship between the years OCPC 07 was in effect and Note size (at the 5\% level of significance for the first year and $1 \%$ for the second year). Confirming the difference of means tests, the years OCPC 07 was in effect are associated with shorter Notes, suggesting that the new guideline caused a reduction in Note size.

In terms of corporate governance, only the variable for being listed in the Novo Mercado (NM) segment is significant ( $1 \%)$ for explaining Note size in the four models; being listed in Nivel 1 (Level 1) was not significant in any of the years analyzed in isolation. These results suggest that the higher the level of the company's corporate governance, the longer its Notes will tend to be.

It is observed that the variables company size (Total Assets), internationalization (ADRs), and economic sector (Energy Sector) have a positive and significant (at 1\%) association with the size of the companies' Notes, confirming that bigger companies from the regulated electrical energy sector and issuers of ADRs on the NYSE tend to have longer Notes. 
Table 2

Regression analysis - Explanatory factors for Notes size

\begin{tabular}{|c|c|c|c|c|c|}
\hline \multirow{2}{*}{ Variables } & \multirow{2}{*}{ Expectation } & \multicolumn{4}{|c|}{ Coefficients (significance) } \\
\hline & & 2013 & 2014 & 2015 & All years \\
\hline \multirow{2}{*}{ Total assets } & + & $1,558^{* * *}$ & $1,613^{* * *}$ & $1,526^{* * *}$ & $1,563 * * *$ \\
\hline & & $(10.83)$ & $(11.43)$ & $(11.66)$ & $(19.49)$ \\
\hline \multirow{2}{*}{ Energy sector } & + & $5,307^{* * *}$ & $6,299 * * *$ & $6,468^{* * *}$ & $5,944 * * *$ \\
\hline & & $(4.45)$ & (5.54) & $(6.11)$ & (9.13) \\
\hline \multirow{2}{*}{ NM } & + & $5,280^{* * *}$ & $3,284^{* * *}$ & $3,285^{* * *}$ & $3,974^{* * *}$ \\
\hline & & $(5.25)$ & $(3.48)$ & $(3.79)$ & $(7.32)$ \\
\hline \multirow{2}{*}{$\mathrm{N} 2$} & + & $5,613^{* * *}$ & 3,048 & $3,853^{* *}$ & $4,305^{* * *}$ \\
\hline & & $(2.77)$ & $(1.59)$ & $(2.24)$ & $(3.95)$ \\
\hline \multirow{2}{*}{ N1 } & + & 2,714 & 1,292 & 1,773 & $1,976^{* *}$ \\
\hline & & $(1.64)$ & $(0.82)$ & $(1.25)$ & $(2.21)$ \\
\hline \multirow{2}{*}{ Aud 1} & + & $5,405^{* * *}$ & $2,099 *$ & 1,567 & $3,147^{* * *}$ \\
\hline & & $(4.33)$ & $(1.71)$ & $(1.37)$ & $(4.52)$ \\
\hline \multirow{2}{*}{ Aud 2} & + & $4,672 * * *$ & $3,624 * * *$ & $3,429 * * *$ & $3,907^{* * *}$ \\
\hline & & $(4.06)$ & $(3.29)$ & $(3.06)$ & $(6.04)$ \\
\hline \multirow{2}{*}{ Aud 3} & + & $6,304^{* * *}$ & $4,248^{* * *}$ & $3,197^{* * *}$ & $4,441^{* * *}$ \\
\hline & & $(4.53)$ & (3.39) & $(3.07)$ & $(6.32)$ \\
\hline \multirow{2}{*}{ Aud 4} & + & $2,490 *$ & $2,511 * *$ & $2,840 * *$ & $2,635^{* * *}$ \\
\hline & & $(1.84)$ & $(1.98)$ & $(2.49)$ & (3.64) \\
\hline \multirow{2}{*}{ ADRs } & + & $9,840 * * *$ & $10,100^{* * *}$ & $10,603^{* * *}$ & $10,110^{* * *}$ \\
\hline & & (5.75) & $(6.26)$ & $(7.24)$ & $(10.96)$ \\
\hline \multirow{2}{*}{2014} & - & & & & $-1,143^{* *}$ \\
\hline & & & & & $(-2.24)$ \\
\hline \multirow{2}{*}{2015} & - & & & & $-1,678^{* * *}$ \\
\hline & & & & & $(-3.24)$ \\
\hline \multirow{2}{*}{ Constant } & & $-10,867^{* * *}$ & $-10,956^{* * *}$ & $-10,162^{* * *}$ & $-9,961 * * *$ \\
\hline & & $(-6.02)$ & $(-6.28)$ & $(-6.34)$ & $(-9.37)$ \\
\hline $\mathrm{R}^{2} \mathrm{a}$ & & $63.8 \%$ & $62.4 \%$ & $66.8 \%$ & $64.3 \%$ \\
\hline $\mathrm{F}$ test & & $56.15^{* * *}$ & $52.99 * * *$ & $62.09 * * *$ & $140.67^{* * *}$ \\
\hline $\mathrm{N}$ & & 314 & 314 & 304 & 932 \\
\hline
\end{tabular}

Notes: the results of the $t$ test are in parentheses.

2014 and 2015: 1 if the data refer to each year Accounting Pronouncements Committee Guideline 07 (OCPC 07) was in effect and 0 otherwise; ADRs (American depositary receipts) $=1$ if the company has ADRs listed on the New York Stock Exchange (NYSE) and 0 otherwise; total assets = Naparian logarithm of total assets; Aud 1, 2, 3, and $4=1$ if the company is audited by each specific Big Four and 0 otherwise; Energy sector = 1 if the company belongs to the electrical energy sector and 0 otherwise; N1: 1 if the company is listed in level 1 corporate governance of the B3 and 0 otherwise; N2: 1 if the company is listed in level 2 corporate governance of the B3 and 0 otherwise; NM = 1 if the company is listed in the Novo Mercado of the B3 and 0 otherwise. $*, * *, * * *=$ levels of significance of 10,5 , and $1 \%$, respectively.

Source: Elaborated by the authors.

Concerning the effect of the auditing company, the results indicate that there is a significant association (at $1 \%$ ) between being audited by Big Fours n. 2 and $n$. 3 (for exemption, the names of the auditors were omitted) and having longer Notes. The association between being audited by Big Fours n. 1 or n. 4 and Note size cannot be established with as much certainty. For Big Four n. 1, both the explanatory power and its statistical significance fall progressively with OCPC 07 being in effect, but the opposite movement is perceived in relation to being audited by auditor $\mathrm{n}$. 4 . These results suggest that not all the Big Four appear to have the same power of influence over the companies they audit in terms of the downsizing of their Notes promoted by OCPC 07.

\subsubsection{Explanatory factors for the variation in Note size after OCPC 07}

Regarding the results of the tests of the explanatory variables for the variation in Note size after OCPC 07 , Table 3 shows the correlation tests for the continuous variables and Table 4 shows the difference of means $t$ tests for the binary variables.

The results in Table 3 indicate a negative significant correlation between the company's size and the index for the variation in Note size (before/after OCPC 07); this correlation rises from $10.5 \%$ in the first year OCPC 07 was in effect to $20 \%$ after two years. The negative correlation with Note size in the year immediately before OCPC 07 came into effect is even greater, at around 23\% 
in the first year and around $31 \%$ after two years of the guideline (both significant at 1\%). These results confirm the expectation that the longer the company's Notes in the year immediately before OCPC 07 and the bigger the company is, the greater the downsizing of its Notes tends to be with the new guideline.

Table 3

Variation in Notes size - Correlation with continuous variables

\begin{tabular}{ccc}
\hline & $\mathbf{2 0 1 3}$ vs 2014 & 2013 vs 2015 \\
\hline Company size (NL Assets) & $-0.105^{*}$ & $-0.200^{* * *}$ \\
\hline Number of words in 2013 & $-0.229^{* * *}$ & $-0.312^{* * *}$ \\
\hline
\end{tabular}

$\mathrm{NL}=$ total asset's naparian logarithm.

$*, * *, * *=$ levels of significance of 10,5, and $1 \%$, respectively.

Source: Elaborated by the authors.
The analysis of the qualitative explanatory variables (Table 4) shows that the companies that downsized their Notes in both periods OCPC 07 was in effect tend to be those listed at the highest corporate governance level of the B3 (Novo Mercado) and those audited by Big Four $\mathrm{n}$. 1. Being audited by Big Four n. 3 is also associated with a reduction in Note size, but only in the second year OCPC 07 was in effect. These results confirm the expectation that the same governance factors (being listed in the highest segment of governance and being audited by a Big Four) that tend to work as an incentive for improving disclosure would also be associated with the downsizing of inflated Notes, promoted by OCPC 07.

Table 4

Variation in Notes size $-t$ test of the binary variables

\begin{tabular}{|c|c|c|c|c|c|c|}
\hline \multirow{2}{*}{ Variable } & \multirow{2}{*}{\multicolumn{2}{|c|}{ Groups }} & \multicolumn{2}{|c|}{$2013 \times 2014$} & \multicolumn{2}{|c|}{$2013 \times 2015$} \\
\hline & & & $\mathbf{N}$ & Mean & $\mathbf{N}$ & Mean \\
\hline \multirow{8}{*}{ Governance } & \multirow{2}{*}{ Differentiated level } & Yes & 144 & $0.920^{* * *}$ & 141 & $0.908^{* * *}$ \\
\hline & & No & 170 & $1.029^{* * *}$ & 163 & $1.036^{* * *}$ \\
\hline & \multirow{2}{*}{ NM } & Yes & 106 & $0.919^{* * *}$ & 103 & $0.904 * * *$ \\
\hline & & No & 208 & $1.009^{* * *}$ & 201 & $1.014^{* * *}$ \\
\hline & \multirow{2}{*}{ N1 } & Yes & 24 & 0.941 & 24 & 0.922 \\
\hline & & No & 290 & 0.982 & 280 & 0.981 \\
\hline & \multirow{2}{*}{$\mathrm{N} 2$} & Yes & 14 & $0.894^{* *}$ & 14 & 0.916 \\
\hline & & No & 300 & $0.983^{* *}$ & 290 & 0.98 \\
\hline \multirow{8}{*}{ Regulated sector } & \multirow{2}{*}{ Regulated sector } & Yes & 61 & $1.031^{*}$ & 59 & 1.075 \\
\hline & & No & 253 & $0.966 *$ & 245 & 0.953 \\
\hline & \multirow{2}{*}{ Telecomunications } & Yes & 13 & 1.037 & 12 & 1.002 \\
\hline & & No & 301 & 0.976 & 292 & 0.976 \\
\hline & \multirow{2}{*}{ Electical energy } & Yes & 42 & 1.026 & 41 & 1.107 \\
\hline & & No & 272 & 0.972 & 263 & 0.956 \\
\hline & \multirow{2}{*}{ Oil and gas } & Yes & 6 & 1.053 & 6 & 1.004 \\
\hline & & No & 308 & 0.978 & 298 & 0.976 \\
\hline \multirow{10}{*}{ Auditing firm } & \multirow{2}{*}{ Some Big Four } & Yes & 212 & $0.954^{* * *}$ & 199 & $0.940^{*}$ \\
\hline & & No & 102 & $1.031^{* * *}$ & 105 & $1.047^{*}$ \\
\hline & \multirow{2}{*}{ Aud 1} & Yes & 48 & $0.881^{* * *}$ & 45 & $0.857^{* * *}$ \\
\hline & & No & 266 & $0.997^{* * *}$ & 259 & $0.997^{* * *}$ \\
\hline & \multirow{2}{*}{ Aud 2} & Yes & 66 & 0.965 & 43 & 0.974 \\
\hline & & No & 248 & 0.983 & 261 & 0.977 \\
\hline & \multirow{2}{*}{ Aud 3} & Yes & 49 & 0.955 & 62 & $0.904 * * *$ \\
\hline & & No & 265 & 0.983 & 242 & $0.995^{* * *}$ \\
\hline & \multirow{2}{*}{ Aud 4} & Yes & 49 & 1.010 & 49 & 1,031 \\
\hline & & No & 265 & 0.973 & 255 & 0,966 \\
\hline \multirow{2}{*}{\multicolumn{2}{|c|}{ ADRs on the NYSE }} & Yes & 20 & 0.968 & 20 & 0.960 \\
\hline & & No & 294 & 0.98 & 284 & 0.978 \\
\hline
\end{tabular}

$A D R=$ American Depositary Receipt NYSE = New York Stock Exchange

$*, * *, * * *=$ levels of significance of 10,5 , and $1 \%$, respectively.

Source: Elaborated by the authors.

An interesting conclusion with regards to Big Four n. 1 can be found by combining the results from Table 4 with those from Table 2. According to Table 4, those companies audited by Big Four n. 1 are the ones that most reduced the size of their Notes in 2014 (average reduction of 12\%), with this downsizing process continuing in 2015 (average 
reduction of 14\%); according to Table 2 , being audited by Big Four n. 1 is a strong indication of longer Notes in 2013 (before OCPC 07), but the power of this variable in explaining longer Notes declines in the years OCPC 07 was in effect, until losing statistical significance in 2015. This suggests that Big Four n. 1 would have caused such a reduction in the size of the Notes of the companies it audited that, in 2015, being audited by this Big Four would no longer indicate longer Notes.

In contrast, the movement towards reducing Note size is not associated with the inferior governance segments (it was significant at $5 \%$ only in 2014 for level 2), nor with all the Big Four (there is no significant association with Big Four n. 2 nor with n. 4). These results suggest that, contrary to what could be expected, not all the Big Four appear to have effectively stimulated the downsizing of the Notes of the companies they audited. Only one of them appears to have carried out a consistent process of downsizing Notes in the two years and another only in the second year OCPC 07 was in effect.
The variables for having a listing on an international stock exchange (ADRs) and belonging to one of the regulated sectors are also not associated with the movement of reducing Note size. One possible explanation may be the difficulty in carrying out changes in disclosure, given the joint regulation of the Brazilian stock exchange (CVM) plus the SEC (in the case of issuers of ADRs on the NYSE) and other specific agencies (in the case of the highly regulated sectors).

\subsection{Analysis of the Note on Accounting Policies of Companies that most Downsized their Notes}

Table 5 presents the indicators of size of the note on accounting policies of the 62 companies whose Notes were reduced by at least $20 \%$ in 2014, the year OCPC 07 was introduced. An expressive reduction is observed in the size of the note, of between $34 \%$ and $45 \%$, depending on the metric used (number of pages, words, or sentences, all significant at $1 \%)$.

Table 5

Size and proportion of the Note on accounting policies after Accounting Pronouncements Committee Guideline 07 (OCPC 07)

\begin{tabular}{|c|c|c|c|c|c|c|c|c|c|c|c|c|}
\hline & \multicolumn{9}{|c|}{ Readability index } & \multirow{2}{*}{\multicolumn{3}{|c|}{$\begin{array}{l}\text { Index of similarity with } \\
\text { the model note }\end{array}$}} \\
\hline & \multicolumn{3}{|c|}{ Words/Sentençe } & \multicolumn{3}{|c|}{ Words/Paragraph } & \multicolumn{3}{|c|}{ Fog Index } & & & \\
\hline & 2013 & 2014 & $2014 / 2013$ & 2013 & 2014 & $2014 / 2013$ & 2013 & 2014 & $2014 / 2013$ & 2013 & 2014 & $2014 / 2013$ \\
\hline Number & 62 & 62 & & 62 & 62 & & 62 & 62 & & 44 & 44 & \\
\hline Mean & 17 & 19 & 1.07 & 25 & 27 & 1.08 & 7.1 & 7.6 & 1.06 & $54.3 \%$ & $50.9 \%$ & 0.94 \\
\hline Median & 18 & 19 & 1.06 & 24 & 27 & 1.14 & 7.3 & 7.7 & 1.06 & $50.8 \%$ & $47.2 \%$ & 0.93 \\
\hline Minimum & 6 & 7 & & 4 & 6 & & 2.7 & 2.8 & & $28.8 \%$ & $29.1 \%$ & \\
\hline Maximum & 25 & 27 & & 54 & 45 & & 10.3 & 10.8 & & $82.0 \%$ & $79.1 \%$ & \\
\hline $\begin{array}{l}\text { Standard } \\
\text { deviation }\end{array}$ & 5 & 4 & & 11 & 8 & & 1.8 & 1.5 & & $12.5 \%$ & $12.8 \%$ & \\
\hline $\begin{array}{l}\text { Percentage of } \\
\text { companies } \\
\text { with reduction }\end{array}$ & & $50 \%$ & & & $48 \%$ & & & $50 \%$ & & & $61 \%$ & \\
\hline Test for mean & & $* *$ & & & * & & & $* *$ & & & $*$ & \\
\hline
\end{tabular}

$*, * *, * *=$ levels of significance of 10,5 , and $1 \%$, respectively.

Source: Elaborated by the authors.

It is observed that there was practically no alteration in the size of this note in relation to the Notes as a whole: the note occupied, on average, $28 \%$ of the size (number of words) of the Notes in the two years. These results suggest that the reduction in size of the Notes in the first year OCPC 07 was in effect appears to have been generalized for all Notes, with no special focus on the note on accounting policies.

The readability indices (Table 6) measure whether, by reducing the size of the note on accounting policies, the company also made it more readable. The results, according to the three readability metrics used (average length of sentences, average length of paragraphs, and Fog Index), are consistent in defying expectations, indicating a deterioration in the readability indicators, with an average increase in the order of 6 to $8 \%$. Some improvement is noted, however, in the readability indices for this note in half of the companies.

The combination of an average fall of $45 \%$ in the number of sentences (Table 5) with an average increase of $7 \%$ in the length of the sentences (Table 6) suggests that, in order to reduce the size of the Notes, the companies appear to have engaged in eliminating whole sentences and/or reducing breaks in sentences, ultimately making them longer. Thus, by neglecting the task of making the sentences more concise and readable, they ended up with more difficult to read Notes. 
Table 6

Indices of readability and of similarity with the model note

\begin{tabular}{|c|c|c|c|c|c|c|c|c|c|c|c|c|}
\hline & \multicolumn{9}{|c|}{ Size of the note on accounting policies } & \multirow{2}{*}{\multicolumn{3}{|c|}{$\begin{array}{l}\text { Proportion of the total for the } \\
\text { Notes (percentage of words) }\end{array}$}} \\
\hline & \multicolumn{3}{|c|}{ Number of words } & \multicolumn{3}{|c|}{ Number of pages } & \multicolumn{3}{|c|}{ Number of sentences } & & & \\
\hline & 2013 & 2014 & 2014/2013 & 2013 & 2014 & 2014/2013 & 2013 & 2014 & $2014 / 2013$ & 2013 & 2014 & 2014/2013 \\
\hline Number & 62 & 62 & & 62 & 62 & & 62 & 62 & & 62 & 62 & \\
\hline Mean & 15 & 9 & 0.62 & 5,204 & 3,451 & 0.66 & 331 & 183 & 0.93 & $28 \%$ & $28 \%$ & 0.99 \\
\hline Median & 14 & 9 & 0.64 & 5,550 & 3,174 & 0.57 & 254 & 185 & 0.87 & $28 \%$ & $26 \%$ & 0.94 \\
\hline Minimum & 1 & 1 & & 198 & 208 & & 16 & 13 & & $5 \%$ & $7 \%$ & \\
\hline Maximum & 43 & 25 & & 11,440 & 8,782 & & 1,620 & 622 & & $54 \%$ & $123 \%$ & \\
\hline $\begin{array}{l}\text { Standard } \\
\text { deviation }\end{array}$ & 10 & 6 & & 3,133 & 2,273 & & 305 & 121 & & $10 \%$ & $17 \%$ & \\
\hline $\begin{array}{l}\text { Percentage of } \\
\text { companies } \\
\text { with a } \\
\text { reduction }\end{array}$ & & $77 \%$ & & & $84 \%$ & & & $79 \%$ & & & $53 \%$ & \\
\hline Test for mean & & $* *$ & & & $*$ & & & $* *$ & & & $*$ & \\
\hline
\end{tabular}

Note: Only Notes on accounting policies. Only companies that maintained their auditor and for which it was possible to calculate the similarity index using the Farejador software.

$*, * *, * * *=$ levels of significance of 10,5 , and $1 \%$, respectively.

Source: Data on companies that reduced by $20 \%$ in 2014.

According to Table 6, the similarity of the company's $\mathrm{EN}$ in relation to the auditor's model note appears to remain constant or fall slightly, from $54.3 \%$ in 2013 to $50.9 \%$ in 2014 (10\% significance), suggesting an almost unperceivable improvement in this indicator. However, $61 \%$ of the companies in the subsample achieved some reduction in the similarity index for their note on accounting policies in relation to the auditor's model note.

The results suggest little effectiveness of OCPC 07 in reducing the undesirable and common practice of copy-pasting texts of the norm or the auditor's template, since, on average, $51 \%$ of the note on accounting policies still consists of such texts, thus opposing the guideline of
OCPC 07 that "in the Notes on the basis for elaborating the financial statements and the specific accounting policies of the entity the texts of the normative acts should not be repeated" (OCPC 07, item 30). Thus, the Brazilian companies still appear resistant to only communicating their real accounting practices and policies in the effective interest of the user.

\subsection{Comparison of Note size in Brazil versus in the United Kingdom}

The reduction in Note size after OCPC 07 leads to a complementary question: was this reduction enough to put the Notes of Brazilian companies at the same size level as British ones, a benchmark for transparency?

Table 7

Footnote size in 2015: Brazil vs. United Kingdom

\begin{tabular}{lccc}
\hline & Brazil & United Kingdom & Brazil/United Kingdom \\
\hline Number & 106 & 176 & 0.6 \\
\hline Pages & & & \\
\hline Mean & 75 & 54 & 1.4 \\
\hline Median & 68 & 51 & 1.3 \\
\hline Minimum & 29 & 162 & 2.9 \\
\hline Maximum & 206 & 22 & 1.3 \\
\hline Standard deviation & 29 & & $0.00 \%$ \\
\hline$t$ test & & & \\
\hline Assets (US\$ 1,000,000) & 7,527 & 9,911 & 0.8 \\
\hline Mean & 2,093 & 2,494 & 0.8 \\
\hline Median & 510 & 525 & 1.0 \\
\hline Minimum & 227,261 & 261,832 & 0.9 \\
\hline Maximum & 23,892 & 27,167 & \\
\hline Standard deviation & & \\
\hline test & & \\
\hline
\end{tabular}

Source: Elaborated by the authors. 
According to Table 7, even after the downsizing promoted by OCPC 07 , the Brazilian companies' Notes are still on average $40 \%$ longer (contrary to expectations for an equivalent number of pages) than those of the British firms (at 1\% significance) of equivalent size and sectors (mean difference tests indicate that there is no significant difference in size between the samples of Brazilian and British companies).

\section{CONCLUSION}

This study analyzes the impact of OCPC 07 on improving formal aspects (size, readability, and specificity) of Brazilian companies' Notes via six questions: (1) Was there a reduction in Note size promoted by OCPC 07? (2) If so, what factors would explain the size and (3) variation in size of the Notes? (4) Was there an improvement in the readability of the text? (5) Was there a decrease in the practice of copy-pasting texts from the norm with an increase in content specific to the company's reality? (6) Two years after OCPC 07 came into effect, had the Notes of Brazilian companies (of the civil law legal-accounting culture) reached a similar size to those of British companies, considered a benchmark of the common law tradition?

The answer to the first question is affirmative: an analysis of all non-financial companies listed in the B3 shows a small, but progressive reduction in Note size, with an average fall of around $10 \%$ two years after OCPC 07 came into effect.

The analysis of the explanatory factors confirms that the size of the Notes can be considered a proxy for the companies' level of disclosure, explained by the same factors normally associated with a greater level of disclosure: company size, good corporate governance practices, being audited by the Big Four, having ADRs on the NYSE, and operating sector (in this case, the electrical energy sector). The results also indicate that the positive association with Note size is different for each level of corporate governance and for each Big Four considered individually. In addition, the regression analysis confirms the negative association between Note size and the years OCPC 07 had been in effect, supporting the expectation of a reduction in Note size as a result of the new guideline.

However, in light of the current finding of inflated Notes, with a loss of information amid irrelevant content, it would be expected that, in the movement towards reducing Notes to gain transparency, the same factors that incentivize disclosure would come into play. Nonetheless, not all the variables that normally promote disclosure were corroborated as explanatory factors for a reduction in Notes. In fact, the results indicate that the bigger the company and the longer the Notes in the year immediately before OCPC 07 came into effect, the greater the reduction in Notes when it was in effect. Yet, this reduction is only observed among companies at the highest level of governance (Novo Mercado) and among those audited by Big Four n. 1 (in both years) and Big Four n. 3 (in 2015 only).

These results reveal that there is much more room for downsizing NEs, especially among smaller companies, those not listed or listed in inferior corporate governance segments of the B3, those audited by Big Fours n. 2 and n. 4, and those not audited by the Big Four. They also show the opportunity for downsizing the Notes of electrical energy companies and issuers of ADRs on the NYSE, even when faced with joint regulation [besides the CVM, of the SEC for ADRs and of the National Electrical Energy Agency (Aneel) for electrical energy companies].

The analysis of the note on accounting policies of the companies that reduced the size of their Notes by at least $20 \%$ reveals that the reduction did not result in an improvement in the readability indicators, but there was a small deterioration. These results suggest that, in the process of reducing their Notes, the companies appear to have eliminated entire sentences and/or sentences breaks, neglecting the task of making the sentences more concise and readable. The analysis of the index for the similarity of the text of this note with the template divulged by the auditor indicates that the undesirable practice of copypasting had at least a small improvement: the average for the similarity index fell by only $6 \%$, falling from $54.3 \%$ literal reproduction of the template in 2013 to $50.9 \%$ in 2014 , at a level of significance of only $10 \%$. Thus, OCPC 07 appears to have had little effectiveness in facilitating the readability of the Notes and in focusing on the real policies adopted by the company.

The comparison between the size of the Notes of the Brazilian and British companies showed that, despite the reduction, two years after OCPC 07 had been in place, the Notes of the Brazilian companies were still, on average, $40 \%$ longer than those of that benchmark.

The results of this study give rise to implications for research on disclosure, as they indicate that by reducing inflated Notes, some of the same factors that promote transparency studied in the literature come into play. They also suggest that the introduction of a standard has effectiveness, although limited, in transforming habits 
rooted in the civil law legal-accounting tradition that hardly incentivizes transparency. Thus, the results give rise to implications for regulators, in that they suggest the need to adopt complementary actions - in the form of incentives and stronger enforcement - to promote transparency in the Brazilian market. They also give rise to implications for companies and market analysts, by indicating that there is still room for improving Notes in terms of size, specificity, and readability, with the aim of improving the understanding of them and enjoying the benefits of increased transparency.

It should be stressed that the results of this study ought to be taken with caution, since the effects of OCPC 07 on the quality of the content disclosed were not analyzed, and indicators of the form of disclosure should be considered, thus leaving space for subsequent research.

\section{REFERENCES}

Akerlof, G. A. (1970). The market for "lemons": quality uncertainty and the market mechanism. Quarterly Journal of Economics, 84(3), 488-500.

Archambault, J. J., \& Archambault, M. E. (2003). A multinational test of determinants of corporate disclosure. The International Journal of Accounting, 38(2), 173-194.

Ball, R. (2006). International Financial Reporting Standards (IFRS): pros and cons for investors. Accounting and Business Research, 36(1), 5-27.

Choudhary, P., Schiotzer, J. D, \& Sturges, J. (2013). Boards, auditors, attorneys and compliance with mandatory SEC disclosure rules. Managerial and Decision Economics, 34(7-8), 471-487.

Daske, H., Hail, L., Leuz, C., \& Verdi, R. (2013). Adopting a label: heterogeneity in the consequences of IFRS adoptions. Journal of Accounting Research, 51(3)495-547.

Dempsey, S. J., Harrison, D. M., Luchtenberg, K. F., \& Seiler, M. J. (2010). Financial opacity and firm performance: the readability of REIT annual reports. Journal of Real Estate Financial Economics, 45(2), 450-470.

Diamond, D. W., \& Verrecchia, R. E. (1991). Disclosure, liquidity and the cost of capital. The Journal of Finance, 46(4), 13251359.

Dye, R. A. (2001). An evaluation of "essays on disclosure" and the disclosure literature in accounting. Journal of Accounting and Economics, 31(1-3), 181-185.

Eaton, T. V., Nofsinger, J. R., \& Weaver, D. G. (2007). Disclosure and the cost of equity in international cross-listing. Review of Quantitative Finance and Accounting, 29(1), 1-24.

European Financial Reporting Advisory Group. (2012). Towards a disclosure framework for the Notes. Feedback Statement on Discussion Paper. Retrieved from http:// www.ifrs.org/ Alerts/PressRelease/Documents/2013/Feedback-StatementDiscussion-Forum-Financial-Reporting-Disclosure-May2013.pdf.

Financial Accounting Standards Board. (2012). Disclosure framework [Discussion Paper]. FASB. Retrieved from http:// www.fasb.org/jsp/FASB/FASBContent_C/ProjectUpdateP age\&cid $=1176156344894$.

Frankenberg-Garcia, A. (2002). Using a parallel corpus to analyse English and Portuguese translations. In: Translation (studies): a crossroads of disciplines. Lisboa: Faculdade de Letras da Universidade de Lisboa.
Frankenberg-Garcia, A. (2014). Understanding Portuguese translations with the help of Corpora. In: Working with Portuguese corpora. London: Bloomsbury.

Glaum, M., Schmidt, P., Street, D. L., \& Vogel, S. (2013). Compliance with IFRS 3- and IAS 36-required disclosures across 17 European countries: company- and country-level determinants. Accounting and Business Research, 43(3), 163204.

Gray, S. J. (1988). Towards a theory of cultural influence on development of accounting systems internationally. Abacus, 24(1), 1-15.

Gunning, R. (1969). The Fog index after twenty years. International Journal of Business Communication, 6(2), 3-13.

Healy, P. M., \& Palepu, K. G. (2001). Information asymmetry, corporate disclosure, and the capital markets: a review of the empirical disclosure literature. Journal of Accounting and Economics, 31(1-3), 405-440.

Hope, O. K. (2003). Firm-level disclosure and the relative roles of culture and legal origin. Journal of International Financial Management and Accounting, 14(3), 218-248.

Hui, K. W., \& Matsunaga, S. R. (2015). Are CEOs and CFOs rewarded for disclosure quality? The Accounting Review, 90(3), 1013-1047.

International Accounting Standards Board. (2014). Disclosure initiative (amendments to IAS 1). Retrieved from https:// www.iasplus.com/en/news/2014/12/di-ias-1.

International Financial Reporting Standards. (2013). Discussion forum, financial reporting disclosure. Feedback statement, May. Retrieved from http://www.aasb.gov.au/admin/file/ content102/c3/ M133_11.3_Discussion_Forum_Financial_ Reporting_Disclosure Feedback_Statement.pdf.

Lambert, R., Leuz, C., \& Verrecchia, R. E. (2011). Information asymmetry, information precision, and the cost of capital. Review of Finance, 16(2), 1-29.

Lehavy, R., Li, F, \& Merkley, K. (2011). The effect of annual report readability on analyst following and the properties of their earnings forecasts. The Accounting Review, 86(3), 1087-1115.

Leuz, C., \& Wysocki, D. P. (2016). The economics of disclosure and financial reporting regulation: evidence and suggestions for future research. Journal of Accounting Research, 54(2), 525-622.

Li, F. (2008). Annual report readability, current earnings, and earnings persistence. Journal of Accounting and Economics, 45(2), 221-247. 
Lo, K., Ramos, F., \& Rogo, F. (2017). Earnings management and annual report readability. Journal of Accounting and Economics, 63(1), 1-25.

Loughran, T, \& McDonald, B. (2014). Measuring readability in financial disclosures. The Journal of Finance, 69(4), 1643-1671.

Lourenço, I. (2013, October). As notas explicativas: uma visão internacional. CPC study group for Notes to Financial Statement. São Paulo, SP.

Martins, D. (2011, October 25 $5^{\text {th }}$ ). Adoção de IFRS dobrará notas explicativas do BNDES. Jornal Valor Econômico.

Martins, T. B. F., Ghiraldelo, C. M., Nunes, M. G. V., Oliveira, O. M., Jr. (1996). Readability formulas applied to textbooks in Brazilian Portuguese. São Carlos: Icmsc-Usp.

Miller, B. P. (2010). The effects of reporting complexity on small and large investor trading. The Accounting Review, 85(6), 2107-2143.

Nobes, C. (2013). The continued survival of international differences under IFRS. Accounting and Business Research, 43(2), 83-111.

Comitê de Pronunciamentos Contábeis. (2014). OCPC 07 Evidenciação na divulgação dos relatórios contábil-financeiros de propósito geral. Retrieved from http://www.cpc.org.br/ CPC/Documentos-Emitidos/Orientacoes/Orientacao?Id=95.

Santos, E. S., Ponte, V. M. R., \& Mapurunga, P. V. (2014a). Disclosure versus materiality: compliance with the firsttime IFRS adoption disclosure requirements (IFRS 1) versus impacts on Brazilian firms' results [Working Paper]. American Accounting Association Annual Meeting. Atlanta, GA.

Santos, E. S., Ponte, V. M. R., \& Mapurunga, P. V. (2014b). Mandatory IFRS adoption in Brazil (2010): index of compliance with disclosure requirements and explanatory some factors of firms reporting. Revista Contabilidade \& Finanças, 25(65), 161-176.
Santos, E. S., Schiozer, R., \& Ponte, V. M. R. (2016). Disclosure under IFRS, legal-accounting traditions and enforcement: comparing ADRs issuers on the NYSE with only locally listed firms [Working Paper]. SSRN. Retrieved from http://ssrn. com/abstract $=2956918$.

Santos, E. S., Silva, F. A. M., Sheng, H. H., \& Lora, M. I. (2016). Compliance with IFRS required disclosure and analysts' forecast errors: evidence from Brazil [Working Paper]. American Accounting Association Annual Meeting. New York, NY.

Securities and Exchange Commission. (1998). A plain English handbook: how to create clear SEC disclosure documents. Washington, D.C.: SEC.

Securities and Exchange Commission. (2011). An analysis of IFRS in practice. Retrieved from http://www.sec.com.

Street, D. L., \& Bryant, S. M. (2000). Disclosure level and compliance with IASs: a comparison of companies with and without U.S. listings and filings. The International Journal of Accounting, 35(3), 305-329.

Street, D. L., \& Gray S. J. (2002). Factors influencing the extent of corporate compliance with International Accounting Standards: summary of a research monography. Journal of International Accounting, Auditing and Taxation, 11(1), 51-76.

Subramanian, R., Insley, R., \& Blackwell, R. (1993). Performance and readability: a comparison of annual reports of profitable and unprofitable corporations. The Journal of Business Communication, 30(1993), 49-61.

Verrecchia, R. E. (2001). Essays on disclosure. Journal of Accounting and Economics, 32(1-3), 97-180.

Zarzeski, M. T. (1996). Spontaneous harmonization effects of culture and market forces on accounting disclosure practices. Accounting Horizons, 10(1), 18-37. 